\title{
Alcohol in the Diet; an Appraisal of Its Relation to Illness
}

\author{
Louis ZG Touyz ${ }^{1 *}$, Leonardo M Nassani ${ }^{1}$ and Sarah JJ Touyz ${ }^{2}$ \\ ${ }^{1}$ Faculty of Dentistry, McGill University, Canada \\ ${ }^{2}$ Pennine Acute NHS Trust, Manchester UK \\ *Corresponding author: Louis ZG Touyz, Faculty of Dentistry, McGill University, Canada
}

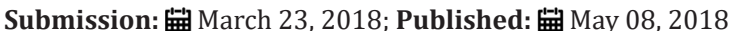

\begin{abstract}
Some global conspiracies promoted in all innocence, dupe people into believing unhealthy eating habits. Consequence of these habits is avoidable illness. Among the major conspiracies is the benign nature of alcohol. This appraisal examines the few advantages, and the many disadvantages, of drinking liquor.
\end{abstract}

Keywords: Alcohol; Cancer; Diet; Drinking; Ethanol

\section{Background}

Yeast fermentation of carbohydrates is an ancient method of producing potable alcoholic beverages. The anaerobic metabolism of the yeast Saccharomyces cerevisiae includes a whole series of enzymes which break down sugars to yield ethyl alcohol [1]. Much has been written about eating a healthy diet. Intakes in various proportions of fats, carbohydrates, proteins and vitamins with supplemental trace elements, as principles dictating sane eating policies which should lead to a healthy lifestyle with optimal metabolism, action packed activity and illness-free longevity [24]. There are some global conspiracies, promoted in all innocence, which dupe many communities into believing unhealthy eating habits are desirable. As with any substance, it's the dose that makes the poison [5]. Many believe if some is good, more is better. The unwanted consequence of this is the development of avoidable illnesses. Among the major conspiracies is drinking alcohol.

\section{Aim}

This appraisal examines some of the advantages and disadvantages of alcoholic beverages.

\section{Alcohol}

As ethyl alcohol, also known as ethanol, is found in minute quantities in nature. Alcohol consumed by humans is usually diluted. Historically "proof" derives from mixing gun-powder with alcohol and testing to see if the mix will ignite [6]. Pure good alcohol allowed the gunpowder to burn up. In the United Kingdom of Great Britain, Europe and Russia, $57.16 \%$ alcohol by volume is considered $100^{\circ}$ proof. In the USA and some other countries marketing to the USA, $100^{\circ}$ proof is $50 \%$ alcohol volume. Accordingly $90^{\circ}$ proof in the USA is in reality only $9 / 10$ of $50 \%$ of alcohol, or $45 \%$ alcohol by volume. Alcohol above this dilution is deemed too dangerous for human consumption. Euro-alcohol is stronger, and will inebriate drinkers with fewer drinks. Beers, stouts and ales have lower concentrations of alcohol; most are at about 4->6\% alcohol by volume. But may be as high as $12 \%$. White wines are usually at $12 \%$, and red wines are more at $12-15 \%$. Champagne is nearly always close to $15-16 \%$ alcohol. Desert and aperitif wines like Sherry, Madeira and Port, can be 18 -> $24 \%$. Spirits and liqueurs vary between 30\% (some liqueurs) and 45\% (spirits including Vodka, Cognac, Brandy, Armanac, Whiskeys and Slivovitz); very rarely is the alcohol $50 \%$ alcohol by volume. Alcohol dilution contents should be stated on the bottle or container label, usually as $\%$ alcohol by volume [6,7]. Alcohol metabolizes at the same rate as carbohydrates ( $1 \mathrm{Gram}=4 \mathrm{Cals}$ ), but is toxic to many cells, mainly liver and neural cells [8]. Most women and some people have a genetic deficiency to produce alcohol dehydrogenase enzyme, which denatures alcohol into metabolic products. These people are prone to becoming drunk on low intakes of alcohol [10,37].

\section{Discussion}

\section{Alcohol}

Alcohol, as ethyl-alcohol, or ethanol, is manufactured by yeasts (Saccharomycetaceae species, mainly S. cerevisiae with anaerobic metabolizing fermenting sources of carbohydrates. Natural sources of mono- and di-saccharides sugars (like glucose, fructose and sucrose from fruits, sugar-cane and beets) as well as polysaccharides (like starches in potatoes, yams and other tubers). Large industries have been developed for the manufacture and distribution of alcohol, and these drinks are marketed as beverages, often with confused messages about promotion of health. Globally 
many cultures have been deceived by promoters of alcohol as a health beverage [11]. Moderation is promoted at two drinks per day for women. Three drinks for men each day, with a break of two days abstinence [12]. Bars, brasseries, restaurants, lounges and speakeasies endorse the chronic inebriation. The motive is profit from booze, not health. Resveratrol in red wines has been shown to reduce the prevalence of coronary heart disease. Resveratrol is available in pill form without any alcohol [13]. But alcohol at low blood levels obtained from as low as two drinks per day, does cause slow but inexorable CNS nerve damage. Alcohol is toxic to metabolism [1319]. Alcohol is notorious as being addictive and alcoholism is as old as recorded history. Alcohol has a direct inhibitory effect on all cognitive abilities including smell, eyesight, neuro-muscular co-ordination, balance, proprioception, hearing and touch [14-17]. Alcohol also damages DNA and is a strong predisposing factor for development of neoplastic changes. Consumers of alcohol have a higher prevalence of cancer formation than those who abstain from alcohol [18-20].

Experimentally, acetaldehyde is a direct metabolite from ethanol, and in hemopoetic stem cells ethanol causes DNA doublestranded breaks. In spite of stimulating recombination repair by p53, damaged chromosomes retain permanent rearrangements [21-36]. The body tries to protect itself against damage caused with alcohol, by using enzymes called aldehyde dehydrogenases (ALDH), that metabolize toxic acetaldehyde into acetate, a benign source of energy. Research shows lacking the critical ALDH enzyme (ALDH2), dilute ethanol results in four times as much DNA damage in cells, compared to cells with fully functioning ALDH2 enzyme [37]. Globally millions of people, many from Southeast Asia, are deficient in the critical ALDH enzyme, (ALDH2) or have faulty versions of them. Accordingly, when they imbibe ethanol blood acetaldehyde increases. Consequent vaso-dilation causes flushing, and drinking small amounts of alcohol results in general nausea. In ALDHdeficient people who are unable to process alcohol effectively, they will have an even higher risk of alcohol related DNA damage, and also a higher rate of induction of carcinogenesis. Alcohol clearance and DNA repair systems are not absolute and alcohol may cause cancer in other ways as well $[10,36]$.

Alcohol is toxic to the liver and a dysfunctional liver is more prone to neoplastic change than a healthy liver [21-24]. Oral cancers are more prevalent in alcohol drinkers that abstainers [24-26]. Smoking more than doubles the risk of cancer for alcohol drinkers [28-30]. That alcohol enhances the taste of drinks is not disputed. Many claim the loosening of inhibition improves the quality of life and makes for a more jovial mood, friendly atmosphere and convivial living. But the same can be achieved without alcohol. Globally many nations have evolved a culture in which alcohol is central, with a multibillion dollar industry supplying a voracious demand which is destructive to society in general, to reducing physical and intellectual vigor, and in general is not needed for healthy living. Bars support a global sophisticated self-deception about refinement and appreciation of tastes inherent in alcoholic products, and this is aggressively encouraged. Huge cash resources endorse the pleasures for drinking liquor, and promote wine, and liquor-tastings, but also surreptitiously regular alcoholdrinking under the guise of savoring the taste. Some religions, like Christianity and Judaism, have enshrined the magic of alcohol in wine, into their faith; this derives from anachronistic times when anaerobic fermentation was considered divinely inspired or deified magic. This is among the grandest pieces of misinformation and horrible hoaxes perpetrated on humanity. If the desire is so great for the taste, why are identical tasting, but alcohol-free drinks, not consumed at the same enthusiastic rate as those with alcohol? The reality is that almost every person that imbibes alcohol does so for the neural effects of the alcohol, and not solely for the taste.

Some drinks are marketed as sugar sweetened flavored fruit drinks (Watermelon, peach, strawberry, lemonade or punch agrumes) with alcohol contents as high as $11.9 \%$ vol/vol, just $0.1 \%$ below the $12 \%$ alcohol content which would dictate [by law in Quebec Canada 2008] to call the drink a wine. In North America laws governing alcoholic drinks are determined at State Level, and as a result liquor-control laws vary from state to state... The drinks are marketed in container-cans, some with over half a liter contents, (568ml), and appeals to teen agers. Two cans would be the equivalent of consuming 8 shots of $40 \%$ vodka, and has proven to be fatal $[36,37]$. The alcohol contents of these drinks which are available in Canada are in Table 1 [37]. Two cans renders enough alcohol to induce drunkenness and possible death in young teenagers. FCKD UP was withdrawn from the market after a report of a 14 year old girl died from rapidly drinking two cans, and others may follow [37,38].

Table 1: Alcohol content of flavored drinks available in North America.

\begin{tabular}{|c|c|c|}
\hline Name & $\begin{array}{c}\text { \% Alcohol Content/ } \\
\text { vol }\end{array}$ & $\begin{array}{c}\text { Size of Can } \\
\text { ml }\end{array}$ \\
\hline Captain Morgan Spiked Brew & $7 \%$ & $473 \mathrm{ml}$ \\
\hline Hard Ice XTRA & $9 \%$ & $710 \mathrm{ml}$ \\
\hline Hard Ice Extra Melon D'eau & $9 \%$ & $710 \mathrm{ml}$ \\
\hline X-TRA Tiki Sangria & $9 \%$ & $710 \mathrm{ml}$ \\
\hline Rev-Up & $10 \%$ & $710 \mathrm{ml}$ \\
\hline Four Loko & $11.90 \%$ & $568 \mathrm{ml}$ \\
\hline FCKD Up & $11.90 \%$ & $568 \mathrm{ml}$ \\
\hline
\end{tabular}

\section{Alcohol contents of sugar-fruit flavored drinks}

Most are over $500 \mathrm{ml}$. The cans are decorated to increase visual appeal each fitted with easy-to-pull opening rings. The inclusion of caffeine in drinks with ethanol allows for masking the effects of alcohol. This confuses consumers, and excess caffeine as well as ethanol-consumption can lead to serious complications, like cardiac arrhythmias and even death [39].

Some call the alcoholic effect "The Buzz" that it induces. In the 19th Century, when social services were minimal and alcoholism was not well understood as an addiction, there was abuse of alcohol and a strong movement of "tee-totallers" or "The Temperance movement" evolved [31-33]. Alcohol was banned and illegal stills, 
shebeens, bars and speak-easies mushroomed. Many unsavory illegal stills had methyl alcohol pollute their product. Methylated alcohol, "Meths" or Wood-alcohol, as it is known, is very poisonous and is often fatal when imbibed [34]. Ethyl alcohol (known as ethanol) was legalized in the 20th Century and subject to consumer constraints (restricting teen-agers from purchasing alcoholic beverages), quality controls and standards of purity, all of which are now enforced by civil laws.

There were an estimated 600,000 new cases of cancers of the head and neck worldwide in 2012 [28] Reducing alcohol drinking in a diet may help to moderate this mortality, but people die from side effects of chronic imbibing when drinking alcohol becomes an addicted habit. In populations who are ALDH-deficient who cannot metabolize alcohol efficiently, have an increase of alcohol related DNA damage, and consequently a higher prevalence of cancer. Alcohol clearance and DNA repair systems are not absolute and alcohol may cause cancer in other ways as well.

"A sin tax "is a state-sponsored tax that is added to products or services that are seen as vices, such as alcohol, tobacco and gambling. These types of taxes are levied by governments to discourage individuals from partaking in such activities without making the use of the products illegal [34]. This has become a 'Cash cow' source of revenue for governments. "In war, politics business and academia, there are no morals, only interests. Touyz 1962" This also seems to apply to people who generate money out of making and marketing booze, as well as to governments who place huge taxes onto the sale of liquor and all alcoholic drinks [33]

\section{Conclusion}

Health warnings and damaging doses should be a compulsory disclosure on foods with high risks of morbidity. Moderation is promoted as being desirable, but few people who drink alcohol observe these recommendations. Alcohol addiction, as alcoholism, persists and is acknowledged as a pathological state demanding social, psychological and medical management. Alcoholic's Anonymous (AA) organization helps those who seek help for their alcohol addiction. What can be done to minimize the disadvantages of alcohol consumption? In principle: One drink a day may be regarded as a beverage; a second drink should be considered as abuse.

\section{References}

1. Compagno C, Dashko S, Piskur J (2014) Introduction to carbon metabolism in yeast. In: Piskur J, Compagno C (Eds.), Molecular mechanisms in yeast carbon metabolism. Springer, Heildelberg, Germany, pp. 1-21.

2. Lichtenstein AH, Appel lJ, Brands M, Carnethon M (2006) Diet and lifestyle recommendations revision 2006. Circulation 114: 82-96.

3. Krauss RM, Eckel RH, Howard B, Appel LJ (2000) AHA dietary guidelines. Circulation 102: 2284-2299.

4. Insel P, Roth W, Irwin J, Burke S (2011) Core concepts in health. Canadian edition. Passim Western health Sciences, 26.

5. Driesbach RH (1969) Handbook of poisoning. Diagnosis and evaluation of poisons, ( $6^{\text {th }}$ edn), Lange Medical publications, USA, pp. 19-35.

6. Jensen WB (2004) The origin of Alcohol Proof. J Chem Educ 81(9): 1258
7. Kerr WC, Greenfield TK, Tijague J, Brwon SE (2005) A drink is a drink? Variation in the amount of alcohol contained in Beer, Wine nd Spirits Drinks in a US Methodological sample. Alcoholism 29(11): 2015-2021.

8. Lieber CS (1991) Perspectives: do alcohol calories count? The American Journal of Clinical Nutrition 54(6): 976-982.

9. Brust JCM (2010) Ethanol and cognition: indirect effects, neurotoxicity and neuroprotection: a review. Int J Environ Res Public Health 7(4): 1540-1557.

10. Crabb DW, EdenbergHJ, Bosron WF, Li TK (1989) Genotypes for aldehyde dehydrogenase deficiency and alcohol sensitivity. The inactive ALDH2(2) allele is dominant. J Clin Invest 83(1): 314-316.

11. Chestnov 0 (2014) Global Status report on alcohol and health 2014 WHO publication, Switzerland.

12. Rotgers F, Kern MF, Hoeltzel R (2002) Responsible Drinking. Passim. New Harbinger Publications, USA, pp. 1-89.

13. Geisler B (2011) Resveratrol. Book Publishing Company, USA, 2(2): 4.

14. The Royal College of Physicians (2005) The great and growing Evil: The medical consequences of alcohol abuse. The Nervous system. Tavistock London and New York 3: 31-42.

15. Maiya RP, Messing R (2014) Alcohol and the neural system. In: Sullivan EV, Pfefferbaum A (Eds.), Handbook of clinical neurology. Peripheral systems: neuropathy. Molecular mechanisms. Elsevier BV 125(3): 518-522

16. Berman OM, Shagrin B, Evert DL, Epstein C (1997) Impairment of brain and behavior. Alcohol Health and Research World 21(1): 65-75.

17. Courtney KC (2016) Health habits and Cognition: The relationship between alcohol consumption, cognitive function and academic performance. Passim Mount Allison University, Canada.

18. Vasilou V, Zakhan S, Seitz HK (2014) Biological basis of alcohol induced cancer. In: Shrotriya S (Ed.), Head and Neck Squamous Cell Carcinoma. Alcohol damage to DNA 19: 338-341.

19. Boffetta P, Hashibe M (2006) Alcohol and cancer. Lancet Oncol 7(2): 149156.

20. Poschl G, Seitz HK (2004) Alcohol and Cancer. Alcohol Alcohol 39(3): 166-165.

21. Salapuro V, Salspuro M (2004) Synergistic effect of alcohol drinking and smoking on in vivo acetaldehyde concentration in saliva. Int J Cancer 111(4): 480-483.

22. Liu C (2018) Precision molecular Pathology of liver cancer. In: Puszyk W (Ed.), Alcohol associated Hepato-cellular Carcinoma, Springer, Germany, pp. 79-85.

23. Blonski W, Kotlyar DS, Forde KA (2010) Non-viral causes of hepato-cellular carcinoma. World J Gatroeneterol 16(29): 3603-3615.

24. Donato F, Tagger A, Gelatti U, PerrinelloG (2002) Alcohol and hepato-cellular carcinoma: the effect of lifetime intake and hepatitis infections in men and women. Am J Epidemiol 155(4): 323-331.

25. Franceshi S, Talamini R, Bara S (1990) Smoking and drinking in relation to cancers of the oral cavity, pharynx, larynx, and esophagus in Northern Italy. Cancer Res 50(20): 6502-6507.

26. Zeka A, Gore R, Kriebel D (2003) Effects of alcohol and tobacco on aero-digestive tractcancer risk; a meta regression analysis. Cancer Causes Cntrol 14(9): 897-906.

27. Brugere J, Guenel P, Leclerc A, Rodriguez J (1986) Differential effects of tobacco and alcohol in cancer of the larynx, pharynx and mouth. Cancer 57(2): 391-395.

28. Rothman KJ, Greenland S, Lash TL (2008) Modern epidemiology. Section II. Study design and conduct. Validity in epidemiological studies. Confounders and surrogate confounders, pp. 130-132. 
29. Detels R, Gulliford M Karim QA (2015) Cancer of the oral cavity, oro-pharynx and hypo-pharynx. Oxford textbook of global public health, UK, pp. 935-936.

30. Blot WJ, McLaughlin JK, Winn DM, Austin DF (1988) Smoking and drinking in relation to oral and pharyngeal cancer. Cancer Res 48(11): 3282 3287.

31. Karcher AJ (1999) New Jerseys Multiple municipal Madness. Part II: Specific issues that cause division, USA, pp. 75-88.

32. Karcher AJ (1999) New Jerseys Multiple municipal Madness. Part 8: Dry towns and wet towns; drawing the line at Abstinence. Happy sad and interesting origins, Rutgers University Press, USA, pp. 112-131.

33. The Temperance movement.

34. Hargreaves T (2016) Poisons and poisoning by stealth. Poison or Medicine 5(6): 136
35. Baily S (2015) Why the alcoholic beverage industry is so highly taxed.

36. Larin V (2018) C'est la fin pour les boissons FCKD UP. Le Journal de Montreal Actualites, p. 2.

37. Lacroix A, Scali D (2018) Les Jeunes ont encore le choix. In: Le Journal de Montreal Actualites, p. 10

38. Garaycoechea JI, Crossan GP, Langevinn F, Muldering L (2018) Alcohol and endogenous aldehydes damage chromosomes and mutate stem cells. Nature 553(7687): 171-177.

39. Touyz LZG (2017) Caffeine in Soft drinks and beverages: sources, Pharmacology and Toxicology. Int Jnl of Medical and Scientific Research 1(2): 31-41.
(C) Creative Commons Attribution 4.0 International License

For possible submissions Click Here
Submit Article

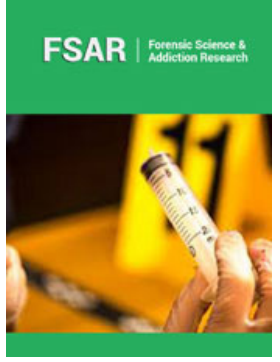

\section{Forensic Science \& Addiction Research}

\section{Benefits of Publishing with us}

- High-level peer review and editorial services

- Freely accessible online immediately upon publication

- Authors retain the copyright to their work

- Licensing it under a Creative Commons license

- Visibility through different online platforms 